\title{
ANALISIS IMPLEMENTASI GREEN BANKING DAN KINERJA KEUANGAN TERHADAP PROFITABILITAS BANK DI INDONESIA (2016-2019)
}

\author{
Diah Anggraini ${ }^{1}$, Dwi Nita Aryani², Irawan Budi Prasetyo ${ }^{3}$ \\ ${ }^{123}$ STIE Malang Kucecwara
}

\begin{abstract}
Abstrak: Green banking adalah aktivitas operasional perbankan yang ramah lingkungan. Penelitian ini menganalisis penerapan green banking, dan kinerja keuangan terhadap profitabilitas bank di Indonesia periode 2016-2019. Sampel penelitian menggunakan metode purposive sampling dan di peroleh 9 bank yang sesuai kriteria. Pengujian data menggunakan analisis regresi berganda. Hasil penelitian menunjukkan bahwa kebijakan green banking berpengaruh positif signifikan terhadap profitabilitas, kecukupan modal tidak berpengaruh negatif signifikan terhadap profitabilitas, kredit bermasalah tidak berpengaruh negatif signifikan terhadap profitabilitas, efisiensi bank berpengaruh negatif signifikan terhadap profitabilitas, tingkat likuiditas bank tidak berpengaruh positif signifikan terhadap profitabilitas.
\end{abstract}

Kata Kunci: Green Banking; CAR; NPL; BOPO; LDR; ROA

Abstract: $\quad$ Green banking is an environmentally friendly banking operational activity. This study analyzes the implementation of green banking and financial performance to profitability of banks in Indonesia period 2016-2019. The research sample used purposive sampling method and obtained 9 banks that match the criteria. Testing data using multiple regression analysis. The results of this study indicate that green banking policy had a significant positive effect on profitability, capital adequacy had no significant negative effect on profitability, non-performing loans had no significant negative effect on profitability, bank efficiency had a significant negative effect on profitability, the level of bank liquidity had no significant positive effect on profitability.

Keywords: Green Banking; CAR; NPL; BOPO; LDR; ROA

\section{PENDAHULUAN}

Munculnya berbagai masalah lingkungan tersebut menjadi perhatian khusus berbagai pihak termasuk pelaku kegiatan ekonomi sehingga setiap organisasi dituntut untuk berperilaku etis sebagai upaya untuk dapat memenuhi tekanan dari pihak eksternal seperti lingkungan dan masyarakat. Salah satu bentuk perilaku etis yang dilakukan organisasi adalah tidak semata-mata hanya fokus pada pencapaian laba (profit) tetapi juga memberikan perhatian pada aspek lingkungan dan masyarakat agar mampu menjaga keberlanjutan dalam jangka panjang. Demi menjaga lingkungan hidup, konsep ekonomi hijau terus digaungkan. Di sektor perbankan pun terdapat istilah green banking. Prinsip dasar dari green banking adalah upaya 
memperkuat kemampuan manajemen risiko bank, khususnya yang terkait dengan lingkungan hidup, dan mendorong perbankan untuk meningkatkan portofolio pembiayaan ramah lingkungan hidup, seperti ke energi terbarukan dan pertanian organik. Green banking adalah bank yang kegiatan operasionalnya ramah lingkungan, memiliki tanggung jawab dan kinerja lingkungan (Bai, 2011). Prinsip dasar green banking adalah upaya memperkuat kemampuan manajemen risiko bank khususnya terkait dengan lingkungan hidup dan mendorong perbankan untuk meningkatkan portofolio pembiayaan ramah lingkungan seperti energi terbarukan, efisiensi energi, pertanian organik, eco-tourism, transportasi ramah lingkungan, dan berbagai produk eco-label. Green banking merupakan sebuah strategi bisnis jangka panjang yang selain bertujuan profit juga mencetak benefit kepada pemberdayaan dan pelestarian lingkungan secara berkelanjutan. Pada dasarnya konsep green banking tidak hanya sekadar menjalankan aktivitas "Go Green". Menurut Bank Dunia, green banking adalah suatu institusi keuangan yang memberikan prioritas pada sustainability dalam praktek bisnisnya dimana bank yang menerapkan konsep green banking akan menghasilkan output perusahaan, competitive advantage, identitas perusahaan yang baik, serta brand image yang kuat dalam pencapaian target perusahaan yang telah ditetapkan. Banyak cara dilakukan dalam adopsi green banking seperti online banking, internet banking, green checking account, green loan, mobile banking, electronic banking outlet dan penghematan penggunaan energi yang berkontribusi pada program keberlanjutan lingkungan (Gupta, 2015). Penelitian yang dilakukan oleh Bhardwaj and Malhorta (2013) menunjukkan bahwa adanya hubungan positif antara penerapan green banking pada profitabilitas bank. Hal senada juga diungkapkan oleh Hossain and Kalince (2014) yang mengatakan bahwa online banking (produk green banking) akan membuat kegiatan bank menjadi lebih efisien dan lebih menguntungkan.

Pada sektor perbankan, profitabilitas digunakan untuk mengukur kinerja bank tersebut. Profitabilitas adalah pertahanan yang utama dalam bank terhadap kerugian yang tidak terduga, seperti memperkuat posisi modal dan meningkatkan profitabilitas masa depan melalui investasi laba ditahan. Menurut Fahmi (2013) profitabilitas yaitu untuk menunjukan keberhasilan perusahaan didalam menghasilkan keuntungan. Investor yang potensial akan menganalisis dengan cermat kelancaran sebuah perusahaan dan kemampuannya untuk mendapatkan keuntungan. Semakin baik rasio profitabilitas maka semakin baik menggambarkan kemampuan tingginya perolehan keuntungan perusahaan. Tingkat profitabilitas bank secara tidak langsung dapat menggambarkan kesehatan suatu bank. Salah 
satunya adalah adanya penerapan green banking yang dapat mempengaruhi profitabilitas suatu bank. Profitabilitas perbankan melalui issue green banking dapat dilihat dari kegiatan operasional yang dilakukan oleh perbankan. Operasional perbankan dalam penelitian ini mengacu pada operasioanl harian yang dilakukan perbankan dalam kinerja sehari-hari dan mengubah praktiknya ke arah yang lebih ramah lingkungan sesuai dengan konsep green banking. Praktik green banking merekomendasikan bahwa dalam hal operasional perbankan jauh lebih baik menerapkan online banking, mobile banking serta green card yang bahannya bisa kembali di daur ulang sehingga bisa lebih paperless (Nath, N \& A, 2014). Perbankan yang menerapkan green banking pada aktivitas kerjanya akan lebih memanfaatkan kemajuan tehnologi serta internet yang sekarang sedang berkembang pesat sehingga aktivitas perbankan yang dulunya based on paper menjadi paperless sehingga di harapkan mengurangi carbon footprint dan carbon emission. Penelitian mengenai pengaruh green banking terhadap profitabilitas pada bank masih menjadi issue baru dan belum banyak dilakukan di Indonesia, sehingga penelitian ini perlu dilakukan untuk dapat memberikan hasil berupa pengetahuan mengenai manfaat penerapan green banking, baik itu bagi masyarakat pada umumnya, perbankan itu sendiri terutama dampaknya terhadap profitabilitas, ataupun untuk pemerintah.

\section{TINJAUAN PUSTAKA}

\subsection{Landasan Teori}

Green banking: Menurut Lalon and Raad (2015) green banking merupakan aktivitas yang utamanya menuju kearah keberlanjutan yakni dengan melakukan upaya perlindungan lingkungan dengan melakukan promosi terkait lingkungan yang hijau (keberlanjutan) dan tanggung jawab investasi terhadap sosial. Menurut Sudhalakshmi and Chinnadorai (2014) green banking berarti melakukan promosi praktek ramah lingkungan dan mengurangi carbon footprint dari aktivitas bank. Menurut Ramila and Gurusamy (2015) green banking ada dua dimensi yang pertama bagaimana sebuah bank terkait operasionalnya dalam aktivitasnya yang lebih memanfaatkan teknologi dan internet sehingga lebih paperless dan dimensi yang kedua adalah green banking yang terkait bank dalam meletakkan dananya, yakni pada kegiatan mendanai atau memberikan kredit pada kegiatan usaha yang tidak memberikan dampak negatif pada lingkungan. 
Kebijakan green banking: Dalam Responsi Bank Indonesia (2014) Undang-Undang Di Indonesia terkait dengan lingkungan dalam Undang-Undang nomor 32 tahun 2009 mengenai perlindungan dan pengelolaan lingkungan hidup. Peraturan ini terkait dengan kegiatan perekonomian yang harus diimbangi dengan upaya melindungi lingkungan dari dampak yang muncul akibat aktivitas tersebut. Bank Indonesia juga mengeluarkan Peraturan Bank Indonesia (PBI) No. 14/15/PBI/2012 tentang Penilaian Kualitas Aset Bank Umum. Dalam peraturan ini, Bank Indonesia mendorong perbankan yang ada di Indonesia untuk mempertimbangkan faktor kelayakan lingkungan dalam melakukan penilaian suatu usaha.

Kecukupan modal: Modal adalah aset utama perusahaan untuk menjalankan bisnis dimana umumnya berbentuk dana atau uang. Menurut Prasanjaya (2013) bank yang memiliki modal tinggi dianggap lebih aman dibanding bank dengan modal yang sedikit, karena bank dengan modal tinggi dianggap memiliki tingkat pembiayaan eksternal yang lebih rendah. Dalam penelitian ini pengukuran kecukupan modal menggunakan rasio CAR (Capital Adequate Rasio).

Kredit Bermasalah: Risiko kredit adalah risiko yang berkaitan dengan kemungkinan kegagalan debitur untuk melunasi hutangnya. Menurut Bilian and Purwanto (2017) risiko yang muncul akibat dari kompleksnya kegiatan perbankan salah satunya adalah risiko kredit atau munculnya NPL. Semakin kompleks aktivitas operasional perbankan cenderung mengakibatkan NPL bank semakin tinggi sehingga risiko kredit pun cenderung meningkat.

Efisiensi bank: Efisiensi perbankan merupakan indikator dalam mengukur kinerja keseluruhan dari aktivitas perbankan. Efisiensi bank dalam penelitian ini diukur menggunakan rasio BOPO. Rasio BOPO sering disebut rasio efisiensi yang digunakan untuk mengukur kemampuan manajemen bank dalam mengendalikan biaya operasional terhadap pendapatan operasional.

Tingkat Likuiditas: Pengukuran Likuiditas diukur dengan rasio LDR dimana likuiditas adalah kemampuan bank dalam menyediakan dana likuid untuk penarikan yang dilakukan para nasabahnya. Tingkat likuiditas digunakan untuk mengukur besar dana dari pihak ketiga yang digunakan untuk kegiatan usahanya dalam bentuk kredit. Hasil penelitian Alifah (2014) menunjukkan bahwa LDR berpengaruh positif terhadap ROA. 
Profitabilitas bank: Menurut Greuning (2005) profitabilitas adalah suatu indikasi atas margin laba suatu perusahaan yang berhubungan dengan penjualan, modal rata-rata, dan ekuitas saham biasa rata-rata. Profitabilitas hasil dari keuntungan yang di dapatkan oleh perusahaan dalam periode tertentu dimana laba suatu perusahaan yang berhubungan dengan semua penjualan, modal dan saham, dimana laba tersebut diukur dalam suatu indikasi dari penjualan perusahaan tersebut agar bisa mendapatakan keuntungan atau laba yang di dapatkan dari hasil penjualan aktiva.

\subsection{Hipotesa}

\section{Green banking dan profitabilitas bank}

Penelitian Bhardwaj and Malhorta (2013) yang meneliti hubungan dari kinerja bank dengan penerapan green banking menunjukkan hasil bahwa adanya hubungan yang positif antara penerapan green banking dengan profitabilitas bank. Awino (2014) melakukan penelitian tentang hubungan antara green banking dengan kinerja keuangan pada bank komersial. Menurut Hossain dan Kalince (2014) green banking berpengaruh signifikan secara prositif pada kinerja bank. Dapat disimpulkan bahwa penerapan green banking mampu memberikan dampak yang positif pada kinerja bank.

Kebijakan green banking diliat dari sisi kebijakan bank yang terkait pada pengurangan penggunaan kertas pada aktivitas operasional harian perbankan. Menurut Albertini (2013) adanya hubungan positif antara kinerja lingkungan terhadap kinerja keuangan bank. Upaya perbankan dalam mengurangi greenhouse gas cenderung akan meningkatkan profitabilitas pada perbankan (Okada, 2010) dengan mengurangi penggunaan kertas memiliki hubungan positif terhadap profitabilitas. Dalam penelitian ini untuk operasional green banking diukur dengan merujuk pada penelitian yang dilakukan Ramila and Gurusamy (2015) untuk mengukur green banking dapat dilakukan dengan melihat transaksi $e$-channel salah satunya adalah transaksi melalui ATM. Sedangkan kebijakan green banking diukur dengan pendekatan model green banking yang dirumuskan oleh Arulrajah \& Shaumya (2018) menggunakan skala dikotomi, nilai 1 akan diberikan jika terdapat pelaporan green banking dan nilai 0 akan diberikan jika sebaliknya. Maka hipotesa dari penjelasan diatas adalah :

H1: Operasional harian green banking berpengaruh pada profitabilitas bank 
H2: Kebijakan green banking bank berpengaruh terhadap profitabilitas bank

\section{Kinerja keuangan dan profitabilitas bank}

Profitabilitas dalam penelitian ini dukur dengan CAR. Menurut Alifah (2014) menunjukan hasil bahwa CAR berpengaruh terhadap ROA. Penelitian oleh Fathurrahman (2012) menunjukkan CAR berpengaruh positif dan signifikan terhadap profitabilitas. Variabel kredit bermasalah diukur dengan rasio non-performing loan (NPL). Semakin tinggi kredit bermasalah akan mempengaruhi profitabilitas bank, karena banyaknya kredit bermasalah menyebabkan pendapatan bank berupa bunga menjadi menurun. Menurut Nusantara (2009) menunjukkan bahwa NPL berpengaruh secara signifikan terhadap ROA. Efisiensi bank yang diukur dengan rasio BOPO, dari hasil penelitian oleh Nusantara (2009) menunjukkan bahwa BOPO berpengaruh secara signifikan terhadap variable ROA. Senada dengan Prasanjaya (2013) dimana BOPO memiliki pengaruh secara signifikan terhadap ROA. Variabel LDR digunakan untuk pengukuran likuiditas dalam penelitian ini. Likuiditas digunakan untuk mengukur besar dana yang digunakan untuk kegiatan usahanya. Penelitian Nusantara (2009) menunjukkan LDR memiliki pengaruh secara signifikan terhadap ROA. Semakin tinggi tingkat likuiditas maka return berupa bunga yang akan didapat bank akan semakin tinggi, sehingga akan meningkatkan profitabilitas. Maka hipotesa dari penjelasan diatas adalah:

H3: Kecukupan modal berpengaruh terhadap profitabilitas bank

H4: Kredit bermasalah berpengaruh terhadap profitabilitas bank

H5: Efisiensi bank berpengaruh terhadap profitabilitas bank

H6: Tingkat likuiditas berpengaruh terhadap profitabilitas bank

\section{METODE PENELITIAN}

Obyek penelitian ini adalah bank yang ada di Indonesia, dengan subyeknya adalah laporan keuangan bank yang menerapkan green banking. Jenis data penelitian menggunakan data sekunder, yakni berupa financial statement yang dikeluarkan oleh bank. Pengambilan sampel menggunakan purposive sampling dengan cara menetapkan kriteria-kriteria sebagai berikut : 
1. Sektor perbankan yang mempublikasikan laporan keuangan secara lengkap selama periode $2016-2019$

2. Perbankan yang menerapkan konsep green banking

3. Perbankan yang menampilkan informasi secara lengkap, mengenai informasi transaksi melalui ATM, e-Banking, laba bersih, dan informasi lain yang diperlukan dalam penelitian.

Pengujian kualitas data dengan menggunakan analisis regresi berganda yang bertujuan untuk memperoleh gambaran yang menyeluruh mengenai hubungan antara variabel satu dengan variabel lain, yang dirumuskan dengan sebagai berikut :

$$
Y=\alpha+\chi_{1}-\chi_{2}+\chi_{3}-\chi_{4}-\chi_{5}+\chi_{6}+\varepsilon
$$

Keterangan :

$$
\begin{aligned}
& \boldsymbol{Y}=\boldsymbol{R O A}(\text { Probalibiltas }) \\
& \alpha=\text { Konstanta } \\
& \chi_{1}=(\mathrm{ATM}) \\
& \chi_{2}=(\mathrm{GB}) \\
& \chi_{3}=(\mathrm{CAR}) \\
& \chi_{4}=(\mathrm{NPL}) \\
& \chi_{5}=(\mathrm{BOPO}) \\
& \chi_{6}=(\mathrm{LDR}) \\
& \chi_{1,2,3,4,5,6}=\text { koefisien regresi } \\
& \varepsilon \quad=\text { Standart error }
\end{aligned}
$$

\section{HASIL PENELITIAN}

Objek pada penelitian ini adalah bank di Indonesia yang mempublikasikan laporan keuangan tahunan mulai periode tahun 2016 sampai dengan tahun 2019. Pengambilan sample dengan 
menggunakan metode purposive sampling sehingga jumlah yang diperoleh sebanyak 36 data (9 (jumlah bank) x 4 (periode penelitian)).

Tabel 4.1

Populasi penelitian

\begin{tabular}{|l|l|l|}
\hline No & Kode & \multicolumn{1}{|c|}{ Nama Bank } \\
\hline 1. & BMRI & Bank Mandiri \\
\hline 2. & BBCA & Bank Central Asia \\
\hline 3. & BBRI & Bank Rakyat Indonesia \\
\hline 4. & BBNI & Bank Negara Indonesia 46 \\
\hline 5. & NISP & Bank OCBC NISP \\
\hline 6. & BNGA & Bank CIMB Niaga \\
\hline 7. & BRIS & Bank Rakyat Indonesia Syariah \\
\hline 8. & INPC & Bank Artha Graha Internasional \\
\hline 9. & BJBR & Bank Jawa Barat dan Banten \\
\hline
\end{tabular}

\subsection{Hasil Uji Asumsi Klasik}




\section{Gambar 4.1. Uji Normalitas Residual dengan Grafik P-P Plot}

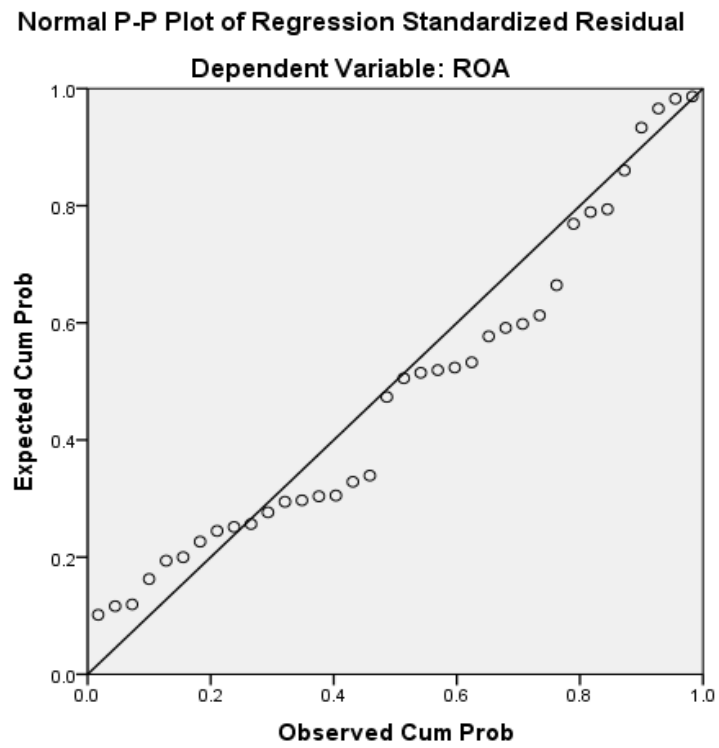

Dari gambar 4.1 hasil uji normalitas residual menggunakan grafik Normal P-P Plot terhadap model regresi linier antara Operasional Green Banking (ATM), Kebijakan Green Banking (GB), Kecukupan Modal (CAR), Kredit Bermasalah (NPL), Efisiensi Bank (BOPO), dan Tingkat Likuiditas Bank (LDR) terhadap Profitabilitas (ROA) diperoleh titik-titik plot berhimpit dengan garis diagonal sehingga residual mengikuti distribusi normal dan asumsi normalitas terpenuhi.

Tabel 4.2. Hasil Uji Normalitas dengan Uji Kolmogorov-Smirnov

\begin{tabular}{|lc|r|}
\hline & & $\begin{array}{r}\text { Unstandardized } \\
\text { Residual }\end{array}$ \\
\hline Normal Parameters ${ }^{\mathrm{a}, \mathrm{b}}$ & Mean & 36 \\
& Std. Deviation & .0000000 \\
& Absolute & .14501113 \\
Most Extreme Differences & Positive & .148 \\
& Negative & -.081 \\
& & .887 \\
Kolmogorov-Smirnov Z & &
\end{tabular}




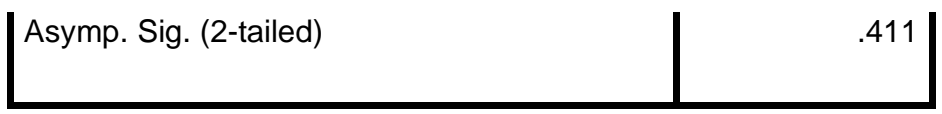

Tabel 4.2 dengan menggunakan uji Kolmogorov-Smirnov terhadap model regresi linier antara Operasional Green Banking (ATM), Kebijakan Green Banking (GB), Kecukupan Modal (CAR), Kredit Bermasalah (NPL), Efisiensi Bank (BOPO), dan Tingkat Likuiditas Bank (LDR) terhadap Profitabilitas (ROA) diperoleh nilai signifikansi sebesar 0,411 (p > 0,05) sehingga residual mengikuti distribusi normal dan asumsi normalitas terpenuhi.

Gambar 4.2. Uji Heteroskedastisita

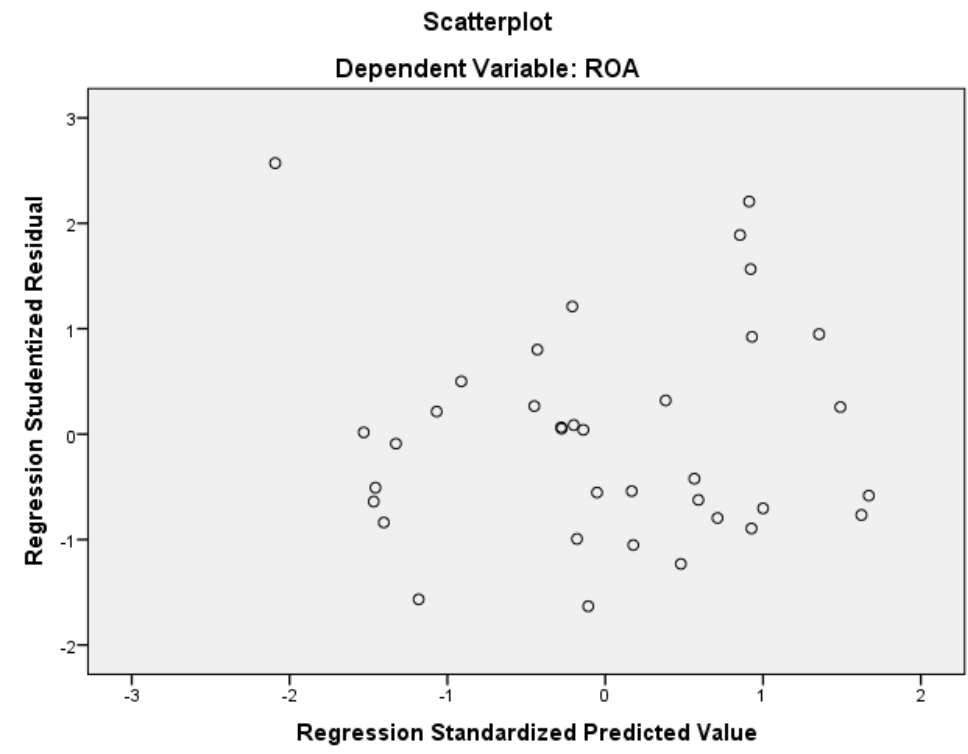

Hasil uji heteroskedastisitas terhadap model regresi linier antara Operasional Green Banking (ATM), Kebijakan Green Banking (GB), Kecukupan Modal (CAR), Kredit Bermasalah (NPL), Efisiensi Bank (BOPO), dan Tingkat Likuiditas Bank (LDR) terhadap Profitabilitas (ROA) dengan menggunakan grafik Scatter plot diketahui titik-titik plot tersebar secara acak dan tidak membentuk pola tertentu sehingga asumsi heteroskedastisitas terpenuhi.

Tabel 4.3. Uji Autokorelasi

\begin{tabular}{|l|l|l|}
\hline Durbin-Watson & $\mathrm{dU}$ & $4-\mathrm{dU}$ \\
\hline 1.807 & 1,776 & 2,224 \\
\hline
\end{tabular}


Dari tabel 4.3 hasil uji autokorelasi dengan uji asumsi autokorelasi dengan uji Durbin Watson terhadap model regresi antara Operasional Green Banking (ATM), Kebijakan Green Banking (GB), Kecukupan Modal (CAR), Kredit Bermasalah (NPL), Efisiensi Bank (BOPO), dan Tingkat Likuiditas Bank (LDR) terhadap Profitabilitas (ROA) diperoleh nilai DW berada dalam rentang nilai dU dan nilai 4-dU sehingga asumsi autokorelasi terpenuhi.

Tabel 4.4 Uji Multikolinieritas

\begin{tabular}{|c|r|r|}
\hline Model & \multicolumn{2}{|c|}{ Collinearity Statistics } \\
\cline { 2 - 3 } & .290 & 3.452 \\
\hline GB & .482 & 2.075 \\
ATM & .637 & 1.569 \\
CAR & .191 & 5.222 \\
NPL & .145 & 6.906 \\
BOPO & .643 & 1.555 \\
LDR & & \\
\hline
\end{tabular}

Hasil uji multikolinieritas terhadap model regresi linier antara Operasional Green Banking (ATM), Kebijakan Green Banking (GB), Kecukupan Modal (CAR), Kredit Bermasalah (NPL), Efisiensi Bank (BOPO), dan Tingkat Likuiditas Bank (LDR) terhadap Profitabilitas (ROA) menggunakan uji VIF diperoleh nilai VIF setiap variabel bebas kurang dari 10 sehingga tidak ditemukan masalah multikolinieritas.

Tabel 4.5 Hasil Koefisien Determinasi

\begin{tabular}{|l|l|l|l|l|}
\hline $\begin{array}{l}\text { Mode } \\
1\end{array}$ & $\mathrm{R}$ & $\mathrm{R}$ Square & $\begin{array}{l}\text { Adjusted } \mathrm{R} \\
\text { Square }\end{array}$ & $\begin{array}{l}\text { Std. Error of } \\
\text { the Estimate }\end{array}$ \\
\hline 1 & $.978^{\mathrm{a}}$ & .956 & .947 & .28015 \\
\hline
\end{tabular}


Hasil koefisien determinasi didapatkan nilai Adjusted R Square sebesar 0,947 yang menunjukkan bahwa variabel dependen Profitabilitas (ROA) dapat dijelaskan oleh variabel independen yaitu Operasional Green Banking (ATM), Kebijakan Green Banking (GB), Kecukupan Modal (CAR), Kredit Bermasalah (NPL), Efisiensi Bank (BOPO), dan Tingkat Likuiditas Bank (LDR) adalah sebesar 94,7 \%, sedangkan terhadap variabel Profitabilitas (ROA) yang ditimbulkan oleh faktor lain adalah sebesar 5,3\% yang tidak disebutkan dalam penelitian ini.

Tabel 4.6. Hasil Regresi Linier Berganda

\begin{tabular}{|c|c|c|c|c|c|c|}
\hline \multirow{2}{*}{\multicolumn{2}{|c|}{ Model }} & \multicolumn{2}{|c|}{$\begin{array}{c}\text { Unstandardized } \\
\text { Coefficients }\end{array}$} & \multirow{2}{*}{$\begin{array}{l}\text { Standardized } \\
\text { Coefficients } \\
\text { Beta }\end{array}$} & \multirow[t]{2}{*}{$\mathrm{t}$} & \multirow[t]{2}{*}{ Sig. } \\
\hline & & $B$ & Std. Error & & & \\
\hline \multirow{7}{*}{1} & (Constant) & 9.212 & .969 & & 9.502 & .000 \\
\hline & GB & -.060 & .209 & -.021 & -.290 & .774 \\
\hline & ATM & .000 & .000 & .124 & 2.202 & .036 \\
\hline & CAR & .015 & .020 & .035 & .720 & .477 \\
\hline & NPL & .080 & .081 & .087 & .981 & .335 \\
\hline & BOPO & -.099 & .010 & -1.012 & -9.880 & .000 \\
\hline & LDR & .003 & .009 & .015 & .304 & .763 \\
\hline
\end{tabular}

ROA $=9,212+0,000107$ ATM - 0,060 GB + 0,015 CAR + 0,080 NPL - 0,099 BOPO + $0,003 \mathrm{LDR}+\mathrm{e}$

Dari persamaan tersebut dapat dijabarkan sebagai berikut:

a. Nilai konstanta (a) sebesar 9,212 menunjukkan tanpa adanya pengaruh dari Operasional Green Banking (ATM), Kebijakan Green Banking (GB), Kecukupan Modal (CAR), Kredit Bermasalah (NPL), Efisiensi Bank (BOPO), dan Tingkat Likuiditas Bank (LDR) maka diperoleh nilai prediksi dari Profitabilitas (ROA) sebesar 9,212 persen. 
b. Nilai koefisien Operasional Green Banking (ATM) sebesar 0,000107 menunjukkan setiap transaksi melalui ATM sebesar 1 juta transaksi akan meningkatkan nilai prediksi dari Profitabilitas (ROA) sebesar 0,000107 persen.

c. Nilai koefisien Kebijakan Green Banking (GB) sebesar -0,060 menunjukkan dengan diberlakukannya penerapan green banking akan menurunkan nilai prediksi dari Profitabilitas (ROA) sebesar 0,060 persen.

d. Nilai koefisien Kecukupan Modal (CAR) sebesar 0,015 menunjukkan setiap peningkatan nilai Kecukupan Modal (CAR) sebesar 1 persen akan meningkatkan nilai prediksi dari Profitabilitas (ROA) sebesar 0,015 persen.

e. Nilai koefisien Kredit Bermasalah (NPL) sebesar 0,080 menunjukkan setiap peningkatan nilai Kredit Bermasalah (NPL) sebesar 1 persen akan meningkatkan nilai prediksi dari Profitabilitas (ROA) sebesar 0,0808 persen.

f. Nilai koefisien Efisiensi Bank (BOPO) sebesar -0,099 menunjukkan setiap peningkatan nilai Efisiensi Bank (BOPO) sebesar 1 persen akan menurunkan nilai prediksi dari Profitabilitas (ROA) sebesar 0,099 persen.

g. Nilai koefisien Tingkat Likuiditas Bank (LDR) sebesar 0,003 menunjukkan setiap peningkatan nilai Tingkat Likuiditas Bank (LDR) sebesar 1 persen akan meningkatkan nilai prediksi dari Profitabilitas (ROA) sebesar 0,003 persen.

Tabel 4.7. Hasil Uji Simultan (F)

\begin{tabular}{|c|c|c|c|c|c|}
\hline Model & Sum of Squares & $\mathrm{df}$ & Mean Square & $\mathrm{F}$ & Sig. \\
\hline $\begin{array}{l}\text { Regression } \\
\text { Residual } \\
\text { Total }\end{array}$ & $\begin{array}{r}49.421 \\
2.276 \\
51.697\end{array}$ & $\begin{array}{r}6 \\
29 \\
35\end{array}$ & $\begin{array}{r}8.237 \\
.078\end{array}$ & 104.948 & $.000^{\mathrm{b}}$ \\
\hline
\end{tabular}


Hasil pengujian secara simultan dengan uji F didapatkan nilai $\mathrm{F}$ hitung $(104,948)$ lebih dari $\mathrm{F}$ tabel $(2,4328)$ atau nilai signifikansi $(0,000)$ kurang dari alpha $(0,050)$ menunjukkan terdapat pengaruh signifikan antara Operasional Green Banking (ATM), Kebijakan Green Banking (GB), Kecukupan Modal (CAR), Kredit Bermasalah (NPL), Efisiensi Bank (BOPO),dan Tingkat Likuiditas Bank (LDR) terhadap Profitabilitas (ROA) secara simultan.

Tabel 4.8 Hasil Uji t

\begin{tabular}{|rr|r|r|}
\hline Model & & \multicolumn{1}{l|}{ Sig. } \\
& & & \\
\hline & (Constant) & 9.502 & .000 \\
& GB & -.290 & .774 \\
& ATM & 2.202 & .036 \\
& CAR & .720 & .477 \\
NPL & .981 & .335 \\
BOPO & -9.880 & .000 \\
LDR & .304 & .763 \\
\hline
\end{tabular}

Dari hasil tabel 4.3 diatas penjabaran untuk pengujian hipotesa adalah :1) Uji parsial antara variabel Operasional Green Banking terhadap ROA didapatkan nilai signifikansi $(0,036)$ kurang dari alpha $(0,050)$ sehingga terdapat pengaruh signifikan dan positif antara Operasional Green Banking terhadap ROA. Pengujian hipotesa untk H1 diterima. 2) Uji parsial antara variabel Kebijakan Green Banking terhadap ROA didapatkan nilai signifikansi $(0,774)$ lebih dari alpha $(0,050)$ sehingga tidak terdapat pengaruh signifikan dan negatif Kebijakan Green Banking terhadap variabel ROA. Pengujian hipotesa untuk $\mathbf{H}_{2}$ ditolak. 3) Uji parsial antara CAR terhadap ROA didapatkan nilai signifikansi $(0,477)$ lebih dari alpha $(0,050)$ sehingga tidak terdapat pengaruh signifikan dan positif antara CAR terhadap ROA. Pengujian hipotesa untuk H3 ditolak. 4) Uji parsial antara NPL terhadap ROA didapatkan nilai signifikansi $(0,335)$ lebih dari alpha $(0,050)$ sehingga tidak terdapat pengaruh signifikan dan positif antara NPL terhadap ROA. Pengujian hipotesa untuk H4 ditolak. 5) Uji parsial antara BOPO terhadap ROA didapatkan nilai signifikansi $(0,000)$ kurang dari alpha $(0,050)$ sehingga terdapat pengaruh signifikan dan BOPO terhadap ROA. Pengujian hipotesa untuk 
H5 diterima. 6) Uji parsial LDR terhadap ROA didapatkan nilai signifikansi $(0,763)$ lebih dari alpha $(0,050)$ sehingga tidak terdapat pengaruh signifikan dan positif antara variabel LDR terhadap ROA. Pengujian hipotesa untuk H6 ditolak.

\section{PEMBAHASAN}

\subsection{Pengaruh Operasional Harian Terhadap Profitabilitas Bank}

Dari hasil penelitian ini menunjukkan bahwa operasional harian green banking terdapat pengaruh secara signifikan dan positif terhadap profitabilitas bank. Hal ini menunjukkan bahwa bank yang menerapkan green banking dalam operasional sehari- hari sudah optimal dalam memanfaatkan teknologi yang ada sehingga kegiatan operasional menjadi lebih efisien dan dari pihak bank secara berkala mengedukasi nasabah untuk bertransaksi secara online agar lebih paperless sehingga dengan memanfaatkan kemajuan teknologi aktivitas yang dilakukan nasabah menjadi lebih mudah karena nasabah dapat bertransaksi dimanapun tanpa harus datang ke cabang, lebih efektif dan efisien, yang mana penggunaan energinya menjadi lebih sedikit dan paperless. Diharapkan dengan mengurangi biaya operasional serta meningkatkan efisiensi mampu meningkatkan profitabilitas bank ini sejalan dengan penelitian oleh Ramila dan Gurusamy (2015) yang menyebutkan bahwa ECS dan ATM berpengaruh terhadap profitabilitas bank.

\subsection{Pengaruh Kebijakan Green Banking Terhadap Profitabilitas Bank}

Dalam penelitian ini kebijakan green banking tidak terdapat pengaruh signifikan dan negatif terhadap profitabilitas bank. Hal ini menunjukkan bahwa bank yang menerapkan konsep green banking dalam aktivitasnya harus memperhatikan dampak negatif lingkungan sekitar. Penelitian ini didukung oleh Bessong and Tapang (2012) yang menunjukkan bahwa kebijakan green banking berpengaruh secara negatif terhadap profitablitas bank.

\subsection{Pengaruh Kecukupan Modal Terhadap Profitabilitas Bank}

Penelitian ini menunjukkan CAR tidak terdapat pengaruh signifikan dan positif terhadap ROA. CAR tidak signifikan karena peraturan dari BI mewajibkan bank menjaga CAR di angka minimal $8 \%$ sehingga bank harus menyiapkan dana lebih atau cadangan untuk memenuhi ketentuan minimal tersebut. CAR yang tinggi harus diimbangi dengan investasi dan penyaluran dana yang baik. Penelitian ini sejalan dengan Defri (2012) CAR tidak 
signifikan terhadap ROA menunjukkan bahwa walaupun modal yang dimiliki bank tinggi tidak akan berdampak terhadap profitabilitas karena bank cenderung untuk menginvestasikan dananya dengan hati-hati dan lebih menekankan pada survival bank sehingga CAR tidak berpengaruh terhadap profitabilitas. CAR tidak berpengaruh bisa juga di sebabkan karena bank tidak mampu untuk menutupi penurunan aktivanya sebagai akibat dari kerugian-kerugian bank yang disebabkan oleh aktiva beresiko (kredit, penyertaan, surat berharha, tagihan pada bank lain) sehingga profitabilitas yang dihasilkan kecil (Usman, 2003). Penelitian ini sejalan dengan Dewi, et.al (2014) menunjukkan bahwa CAR tidak terbukti mempunyai pengaruh yang signifikan terhadap ROA pada bank umum yang terdaftar di Bursa Efek Indonesia.

\subsection{Pengaruh Kredit Bermasalah Terhadap Profitabilitas Bank}

Pada penelitian ini NPL tidak terdapat pengaruh signifikan dan positif terhadap ROA. Hasil ini menunjukkan bahwa pada saat ini tingkat NPL masih di kategorikan rendah. Kualitas kredit yang kurang baik akan meningkatkan risiko, terutama bila pemberian kredit dilakukan dengan tidak menggunakan prinsip kehati-hatian dan ekspansi dalam pemberian kredit yang kurang terkendali sehingga bank akan menanggung risiko tersebut. Risiko yang ditanggung adalah kesulitan dalam pengembalian kredit oleh debitur yang apabila jumlahnya cukup besar mampu mempengaruhi kinerja bank. Hasil temuan ini mendukung hasil penelitian dari Suyono (2005) dan Usman (2003) yang menunjukkan bahwa Non Performing Loan (NPL) tidak berpengaruh signifikan terhadap Return On Asset (ROA).

\subsection{Pengaruh Efisiensi Bank Terhadap Profitabilitas Bank}

Hasil penelitian ini menunjukkan bahwa BOPO terdapat pengaruh signifikan dan negatif yang artinya apabila terjadi peningkatan BOPO maka profitabilitasnya akan mengalami penurunan. Jika bank efisien dalam menekan biaya operasionalnya maka bank dapat mengurangi kerugian akibat ketidakefisien bank dalam hal pengelolaan usahanya. Bank harus mengidentifikasi sumber risiko operasional dan memonitor aktivitas operasionalnya sehingga pengeluaran bank bisa diminimalkan. Besarnya rasio BOPO karena tingginya biaya dari dana yang dihimpun dan rendahnya pendapatan bunga dari penanaman dana. Sehingga semakin besar BOPO, maka akan semakin menurunnya kinerja keuangan perbankan. Peraturan BI menetapkan BOPO yang baik dibawah angka $85 \%$ jika BOPO berada di angka lebih dari $85 \%$ dan cenderung mendekati angka $100 \%$ maka bank tesebut bisa dikatakan tidak efisien 
dalam menjalankan aktivitas operasional perbankan sehingga mengakibatkan profit bank menurun. Hasil temuan ini mendukung hasil penelitian dari Sumiati (2009) dan Alifah (2014) yang menunjukkan bahwa adanya pengaruh yang signifkan antara BOPO terhadap ROA.

\subsection{Pengaruh Likuiditas Bank Terhadap Profitabilitas Bank}

Hasil penelitian ini menunjukkan bahwa LDR tidak terdapat pengaruh signifkan dan positif terhadap ROA. Dengan tidak berpengaruhnya LDR terhadap ROA ini kemungkinan karena besarnya kepemilikan aset, dan kemungkinan yang kedua adalah pendapatan bank dewasa ini tidak hanya dari pendapatan bunga dari pinjaman yang diberikan kepada masyarakat tetapi juga dihasilkan dari pendapatan berbasis komisi. Seperti artikel yang dimuat dalam bisnis.com (2013) yang menyatakan bahwa perbankan sudah mulai berpindah dari fokus untuk mendapat pendapatan dari bunga ke fee-based income. Karena kenyataannya pada saat ini nasabah juga makin banyak yang butuh kemudahan dalam transaksi, asuransi dan investasi. Penelitian ini didukung oleh hasil penelitian oleh Miftah Agustin Safariah (2015), Risky Avrital (2014) dimana dalam penelitiannya juga menemukan hasil bahwa LDR tidak berpengaruh pertumbuhan laba dan ROA karena semakin besar resiko penyaluran kredit terhadap pihak ketiga maka semakin besar pula resiko kredit macet.

\section{KESIMPULAN DAN SARAN}

Berdasarkan hasil penelitian dan pembahasan diatas dapat disimpulkan bahwa : 1) Operasional harian green banking berpengaruh positif signifikan terhadap ROA. 2) Kebijakan Green Banking berpengaruh negatif tidak signifikan terhadap ROA. 3) CAR berpengaruh positif tidak signifikan terhadap CAR. 4) NPL berpengaruh positif tidak signifikan terhadap ROA.5) BOPO berpengaruh negatif tidak signifikan terhadap ROA. 6) LDR berpengaruh positif tidak signifikan terhadap ROA.

Dari penjabaran kesimpulan diatas saran untuk perbankan adalah bagi bank yang sudah menerapkan konsep tersebut diharapkan tetap mempertahankan dan secara berkala meningkatkan aktivitas green dalam menjalankan usahanya. Hasil dari penelitian diatas diketahui bahwa variabel kebijakan green banking dan efisiensi bank (BOPO) berpengaruh terhadap profitabilitas bank sehingga adopsi green banking dalam perbankan harus didukung penuh dalam hal penguatan pemanfaatan tehnologi informasi secara elektronik untuk 
mendukung aktivitas paperless pada operasional sehari-hari. Hal ini diperlukan agar setiap bank di Indonesia berkontribusi dan mendukung implementasi peraturan OJK No 51/PJOK.03/2017 tentang Program Keuangan Bagi Lembaga Jasa Keuangan, Emiten, dan Perusahaan Publik dalam menerapkan manajemen risiko dan lingkungan hidup dalam proses bisnis keuangan. Dan bagi peneliti diharap kan penelitian ini dapat dijadikan wawasan baru mengenai praktik green banking.

\section{DAFTAR PUSTAKA}

Alifah, Y. B. (2014). Pengaruh CAR, NPL, BOPO, dan LDR Terhadap Profitabilitas Bank (ROA) Fakultas Ekonomi Universitas Negeri Yogyakarta, i-128.

Andreas, H. H., Sucahyo, U. S., \& Elisabeth, D. (2015). Corporate Social Responsibility Dan Profitabilitas. Jurnal Manajemen, Vol 14, 119-136.

Awino, O. B. (2014). The Relationship Between Green Banking And Finance Performance Of Commercial Banks In Kenya Business Administration, University Of Nairobi, i55 .

Dewi, L. E., Herawati, N. T., Erni, L. G., \& Sulindawati. (2015). Analisis Pengaruh NIM, BOPO, LDR, dan NPL Terhadap Profitabilitas. e-Journal S1 Ak. Universitas Pendidikan Ganesha, volume 3.

Dialysa, F. (2015). Green Banking: One Effort To Achieve The Principle Of Good Corporate Governance (GCG). First International Conference on Economics and Banking, 128- 132.

Fahmy, M. S. (2013). Pengaruh CAR, NPF, BOPO dan FDR Terhadap Profitabilitas Bank Umum Syariah. $\quad$ Fakultas Syariah dan Hukum Universitas Islam Negeri Sunan Kalijaga Yogyakarta, i-82.

Hossain, D. M., Bir, A. T. S. A., Tarique, K. M., \& Momen, A. (2016). Disclosure of Green Banking Issues in the Annual Reports: A Study on Bangladeshi Banks. Middle East Journal Of Business, Vol 11(Issue 1), 19-30.

Hossain, S., \& Kalince, T. A. (2014). Green Banking Nexus Banks' Performance. Swiss Journal of Research in Business and Social Sciences, Vol 1, 1-17. Islam, M. S., 
\& Das, P. C. (2013). Green Banking practices in Bangladesh. IOSR Journal of Business and Management, Vol 8 (Issue 3), 39- 44.

Isramiarsyh, A. (2016). Analisis Pengaruh Risiko Kredit, CAR, BOPO, LDR Terhadap Profitabilitas Fakultas Ekonomi dan Bisnis Universitas Hadanuddin Makassar, i-66.

Iwata, H., \& Okada, K. (2010). How does environmental performance affect financial performance? Evidence from Japanese manufacturing firm. Faculty of SocioEnvironmental Studies, Fukuoka Institute of Technology, Japan, 1- 27.

K.Shaumya, \& Arulrajah, A. A. (2016). Measuring Green Banking Practices: Evidence from Sri Lanka. International Conference on Business Management 999- 1023.

K.Sudhalakshmi, \& K.M.Chinnadorai. (2014). Green Banking Practices In Indian Banks.

International Journal of Management and Commerce Innovations, Vol 2 (Issue 1), 232-235.

Meena, R. (2013). Green Banking: As Initiative for Sustainable Development. Global Journal of Management and Business Studies, Vol 3, 1181-1186.

Nath, V., Nayak, N., \& Goel, A. (2014). Green Banking Practices-A Review. International Journal of $\quad$ Research in Business Manajement, Vol 2(Issue 4), 46-61.

Nistantya, D. S. (2010). Pengaruh Corporate Social Responsibility Terhadap Profitabilitas Profitabilitas Perusahaan. Fakultas Ekonomi Universitas Sebelas Maret Surakarta, 1- 1xvii.

Nusantara, A. B. (2009). Analisis Pengaruh NPL, CAR, LDR, dan BOPO Terhadap Profitabilitas Bank. Universitas Diponegoro.

Oyewole, O. S., Abba, M., El-maude, Gambo, J., Arikpo, \& Abam, I. (2013). E-banking and Bank Performance: Evidence from Nigeria. International Journal of Scientific Engineering and Technology, Vol 2(Issue 8), 766-771. 
Prasanjaya, A. A. Y. (2013). Analisis Pengaruh Rasio CAR, BOPO, LDR dan Ukuran Perusahaan Terhadap Profitabilitas Bank yang Terdaftar Di BEI. E-Jurnal Akuntansi Universitas Udayana, 230-245.

Ragupathi, \& Sujatha. (2015). Green Banking Initiatives of Commercial Banks in India. International Research Journal of Business and Management, Vol VIII(Issue 2), 74- 81.

Raharjo, D. P. A., Setiaji, B., \& Syamsudin. (2014). Pengaruh Rasio CAR, NPL, LDR, BOPO, dan NIM terhadap Kinerja Bank Umum Di Indonesia. BTPN Solo, 7-12.

Ramila, M., \& Gurusamy, S. (2015). Impact of Green Banking Initiatives Adopted by Public Sector Banks on Profitability. Journal of Management Research, Vol 5(Issue 2), 60- 68.

Rauf, S., \& Qiang, F. (2014). Integrated Model to measure the Impact of E-Banking Services on Commercial banks' ROE: Empirical Study of Pakistan. 3rd International Conference on Information, Business and Education Technology (ICIBET 2014), 19- 22.

Responsi Bank Indonesia (2014). Mengawal Green Banking Indonesia dalam Kerangka Pembangunan Berkelanjutan. http://responsibank.id/media/60528/mengawalgreenbanking-indonesia.pdf. Diakses pada 19 April 2017

Ritu. (2014). Green Banking: Opportunities And Challenges. International Journal of Informative \& Futurintic Research, Vol 2(Issue 1), 34-37.

Sabharwal, M. (2013). The Use Of Eco-Friendly Technology and Green Methods to Bring Down The Carbon Footprint By Indian Banks. Masters International Journal of Management Research and Development (MIJMRD), Vol I(Issue 1), 76-85.

Sahoo, B. P., Singh, A., \& Jain, N. (2016). Green Banking In India: Problems and Prospects. International Journal of Research-Granthaalayah, Vol 4(Issue 8), 92-99. 
Saravanaselvi, C., \& Sangeetha, G. (2016). Green Banking In India. Primax International Journal of C Commerce and Management Research, Vol IV (Issue 3), 119-121.

Shaumya, S., \& Arulrajah, A. (2017). The Impact of Green Banking Practices on Bank Environmental Performance: Evidence from Sri Lanka. Journal of Finance and Bank Management, Vol 5, 77-90.

Singh, Y. (2015). Environmental Management Through Green Banking: A study of Commercial Banks in India. International Journal of Interdisciplinary and Multidisciplinary Studies (IJIMS), Vol 2, 17- 26.

Sorumluluk, K. S., \& Finansal, B. (2015). The Relationship between CSR and Banks' Financial Performance: Evidence from Turkey. E-Journal of Yasar University(Special Issue), 21-30.

Sumiati, S. (2009). Analisis Pengaruh CAR, NPL, LDR, NIM, dan BOPO Terhadap Tingkat Profitabilitas (ROA) pada Bank Muamalat Indonesia. Fakultas Ekonomi dan Ilmu Sosial UIN Syarif Hidayatullah, i-113.

Yadav, S., \& Viswanadham, B. K. (2016). Green banking in India : An inovative initiative for sustainable development. International Journal of Academic Research, Vol 3(Issue 3 ), 88-96.

Yogianta, C. W. E. (2013). Analisis Pengaruh CAR, NIM, LDR, NPL Dan BOPO Terhadap Profitabilitas Jurnal Bisnis Strategi, Vol. 22, 94-111. 